\title{
Deoxyribonucleic Acid Homology in Yeasts. Genetic Relatedness within the Genus Candida
}

\author{
By A. LETH BAK AND A. STENDERUP \\ Institute of Medical Microbiology, University of Aarhus, Denmark
}

(Accepted for publication 15 July 1969)

SUMMARY

The DNA-RNA hybrid technique of Gillespie \& Spiegelman (1965) was used to measure the genetic relatedness among ten different species within the genus Candida and among three of these species and their counterparts within perfect genera. Close relationships were found between Candida albicans (guanine + cytosine content $(\% \mathrm{GC}), 35 \cdot \mathrm{I})$, C. claussenii ( $\% \mathrm{GC}$, $34.9)$ and $C$. stellatoidea $(\% \mathrm{GC}, 35.7)$, which showed a relative homology of 63 to $73 \%$, and between C. brumptii ( $\% \mathrm{GC}, 54 \cdot \mathrm{I})$ and $C$. catenulata $(\% \mathrm{GC}, 54 \cdot 5)$, relative homology $75 \%$. Very close relationships were seen between the three pairs of perfect and imperfect counterparts, $C$. pelliculosa $(\% \mathrm{GC}, 36.8)$ and Hansenula anomala $(\% \mathrm{GC}, 36.6)$, relative homology $8 \mathrm{I} \%$, C. melinii $(\% \mathrm{GC}, 40.9)$ and $H$. wingei $(\% \mathrm{GC}, 4 \mathrm{I} \cdot 2)$, relative homology $97 \%$, and $C$. pseudotropicalis $(\% \mathrm{GC}, 4 \mathrm{I} \cdot 3)$ and Kluyveromyces fragilis $(\% \mathrm{GC}, 4 \mathrm{I} \cdot 6)$, relative homology $92 \%$. Some degree of homology $(32 \%)$ was also found between $C$. pelliculosa and $C$. pseudotropicalis. The relatedness between $C$. albicans and the seven other Candida species (\% GC, 36.6 to $57 \cdot 6$ ) examined was low, relative homology 4 to $13 \%$. This also applies to C. tropicalis $(\% \mathrm{GC}, 34.9)$.

\section{INTRODUCTION}

The use of nucleic acid homology techniques has proved valuable in determining genetic relatedness among micro-organisms including various bacteria (Weissman, Reich, Somerson \& Cole, I966; De Ley, Park, Tijtgat \& van Ermengem, I966) and mycoplasmas (Somerson et al. I 966. One of the methods for determining DNA-RNA hybrid formation is the technique described by Gillespie \& Spiegelman (1965).

In this paper we present an adaptation of this nucleic acid homology method to the study of genetic relatedness among yeasts. The results are presented as percentage binding in heterologous reactions relative to that of the homologous reactions, and for some reactions also as relatedness values with confidence limits for indistinguishable DNA preparations. The concept 'relatedness value', which is defined as the product of the heterologous DNA-RNA reaction yields divided by the product of the homologous reaction yields in the reciprocal reactions between two nucleic acids, is introduced to allow the application of a two way analysis of variance (Alling, 1967). This statistical method is valid only when comparisons are being made between reactions having the same reaction rate constant. This requirement will probably demand for example an alike GC content and genome size for the compared DNAs. The method is used thus in this work only when discriminations between closely related yeast species are required. The yeasts studied were ten different species selected 
from the genus Candida. Previous study of the DNA base composition suggested considerable genetic heterogeneity among many of the species belonging to this genus (Stenderup \& Leth Bak, 1968). The expected heterogeneity in genetic relatedness among species with different DNA base compositions was confirmed by the nucleic acid homology technique. This heterogeneity was further elucidated by the fact that three of the Candida species examined were found to be indistinguishable from their suggested perfect forms in the genera Hansenula and Kluyveromyces. The method also allowed differentiation of species which, on the basis of biological properties and base composition, were suspected to be very closely related.

\section{METHODS}

Organisms. The name and source of each yeast species investigated together with the average per cent GC (guanine + cytosine) are listed in Table I. All species were reclassified according to Lodder \& Kreger-van Rij (1952).

Table I. Source, DNA base composition and \% relative homology* of the yeast species investigated

\begin{tabular}{|c|c|c|c|c|c|c|}
\hline \multirow[b]{2}{*}{ Species } & \multirow[b]{2}{*}{ Source } & \multirow[b]{2}{*}{$\%$ GC } & \multicolumn{4}{|c|}{$\%$ Relative homology } \\
\hline & & & C. albicans & $\begin{array}{l}\text { C. claus- } \\
\text { senii }\end{array}$ & $\begin{array}{l}\text { C. stella- } \\
\text { toidea }\end{array}$ & \\
\hline $\begin{array}{l}\text { Candida albicans } \\
\text { C. claussenii } \\
\text { C. stellatoidea } \\
\text { C. tropicalis }\end{array}$ & $\begin{array}{l}\text { CBS } \dagger 2712 \\
\text { CSAV§ } 29-3 I-I \\
\text { CBS I } 905 \\
\text { CBS I } 20 / 5\end{array}$ & $\begin{array}{l}35 \cdot 1 \ddagger \\
34 \cdot 9 \ddagger \\
35 \cdot 7 \ddagger \\
34 \cdot 9 \ddagger\end{array}$ & $\begin{array}{l}-\overline{6} \\
63 \% \\
73 \% \\
8 \%\end{array}$ & $\begin{array}{l}- \\
\overline{73 \%} \\
7 \%\end{array}$ & $\begin{array}{l}- \\
\overline{9 \%}\end{array}$ & \\
\hline C. tropicalis & & & C. albicans & $\begin{array}{l}\text { C. pelli- } \\
\text { culosa }\end{array}$ & $\begin{array}{l}\text { C. meli- } \\
\text { nii }\end{array}$ & $\begin{array}{l}\text { C.pseudo- } \\
\text { tropicalis }\end{array}$ \\
\hline $\begin{array}{l}\text { C. pelliculosa } \\
\text { Hansenula anomala } \\
\text { C. melinii } \\
\text { Hansenula wingei } \\
\text { C. pseudotropicalis } \\
\text { Kluyveromyces } \\
\quad \text { fragilis }\end{array}$ & $\begin{array}{l}\text { CBS605 } \\
\text { CBS IIO } \\
\text { CBS60I } \\
\text { CBS 243I } \\
\text { CBS607 }\end{array}$ & $\begin{array}{l}36 \cdot 8 \ddagger \\
36 \cdot 6 \| \\
40 \cdot 9 \ddagger \\
4 \mathrm{I} \cdot 2 \| \\
4 \mathrm{I} \cdot 3 \ddagger\end{array}$ & $\begin{array}{r}11 \% \\
12 \% \\
7 \% \\
4 \% \\
8 \%\end{array}$ & $\begin{array}{l}\overline{81 \%} \\
15 \% \\
-\overline{32} \%\end{array}$ & $\begin{array}{l}\overline{-} \\
\overline{9} \\
97 \% \\
11 \%\end{array}$ & $\begin{array}{l}z \\
z\end{array}$ \\
\hline $\begin{array}{l}\text { Kluyveromyces } \\
\text { fragilis }\end{array}$ & & & \multicolumn{4}{|c|}{ C. albicans $C$. brumptii C. catenulata } \\
\hline $\begin{array}{l}\text { C. brumptii } \\
\text { C. catenulata } \\
\text { C. zeylanoides }\end{array}$ & $\begin{array}{l}\text { CBS } 564 \\
\text { CBS 565 } \\
\text { CBS619 }\end{array}$ & $\begin{array}{l}54 \cdot 1 \ddagger \\
54 \cdot 5 \ddagger \\
57 \cdot 6 \ddagger\end{array}$ & $\begin{array}{l}10 \% \\
13 \% \\
11 \%\end{array}$ & $\begin{array}{l}-\overline{75} \% \\
17 \%\end{array}$ & $\frac{-}{22 \%}$ & \\
\hline
\end{tabular}

* The $\%$ relative homology values are calculated from the results in Tables $2-7$, as the average of the relative bindings in reciprocal heterologous reactions.

$\dagger$ Centraalbureau voor Schimmelcultures, Baarn, Netherlands.

\$ Stenderup \& Leth Bak (1968).

$\S$ Czechoslovak Collection of Micro-Organisms.

|| Calculated from melting temperature (Tm) in SSC.

Medium and cultivation techniques. The yeasts were cultivated in Io-litre fermentors (Biotec, Stockholm, Sweden). The liquid medium contained $(\%, w / v)$ : glucose $\mathrm{I} \cdot 0$, peptone (Orthana) I $\cdot 0$, yeast extract (Oxoid) 0.5 and $\mathrm{K}_{2} \mathrm{HPO}_{4} \mathrm{O}^{\circ} \mathrm{I}$. The $\mathrm{pH}$ was adjusted to 5.6 and maintained at this level by automatic titration. The incubation temperature was $30^{\circ}$, and the cultures were abundantly aerated. After growth for one day, 
the yeasts were harvested by centrifugation in a Sorvall continuous flow system at $4^{\circ}$, $10,000 \mathrm{~g}, 500 \mathrm{ml} . / \mathrm{min}$. Tests for bacterial contamination were made by direct microscopic examination and plating on blood agar immediately before centrifugation.

Preparation of $D N A$. The cells were washed three times in cold saline EDTA ( 0.15 $\mathrm{M}-\mathrm{NaCl}+0.1 \mathrm{M}$-ethylenediaminetetraacetate (EDTA)), at $\mathrm{pH} 8.0$ and suspended in an equal volume of a buffer containing $60 \%$ sucrose, $0.5 \mathrm{~mm}-\mathrm{MgCl}_{2}, 0.02 \mathrm{M}-\mathrm{K}_{2} \mathrm{HPO}_{4}$ at $\mathrm{pH} 7.5$ and $0.02 \%$ Triton X-100. To $20 \mathrm{ml}$. of this thick suspension were added $50 \mathrm{~g}$. of glass beads $(0.45 \mathrm{~mm}$.) and the mixture treated in a Braun homogeniser (Braun, Melsungen, Germany) for I min. at maximum speed. The apparatus was cooled with liquid $\mathrm{CO}_{2}$. The broken cell suspension was diluted with the $60 \%$ sucrose buffer and centrifuged in rotor type 19 of the Spinco model L-2 preparative ultracentrifuge at $18,000 \mathrm{rev} . / \mathrm{min}$. for $2 \mathrm{hr}$. DNA was isolated from the sediment by the method of Marmur (I96I) with the following modifications: Lysis with sodium dodecyl sulphate was carried out for Io min. at $37^{\circ}$, after which intact cells and cell debris were sedimented and the supernatant heated at $60^{\circ}$ for Io min. After two deproteinizations with chloroform-isoamyl alcohol, the nucleic acid solution was treated with pronase (Calbiochem) I mg. $/ \mathrm{ml}$. at $60^{\circ}$ for $4 \mathrm{hr}$. All protein was now removed by the chloroform-isoamyl alcohol treatment and RNA digested with a mixture of pancreatic and $\mathrm{T}$ I ribonuclease. To ensure that the final isopropanol precipitate was free of traces of ribonucleases, the extraction procedure was completed by treatment of the DNA with self-digested pronase $50 \mu \mathrm{g}$. $/ \mathrm{ml}$. for $2 \mathrm{hr}$ at $37^{\circ}$ (Gillespie \& Spiegelman, 1965) and finally two or more extractions of the DNA with water-saturated redistilled phenol. The purified DNA was dissolved in $0.0 \mathrm{I} \times \mathrm{SSC}$ (SSC is $0.15 \mathrm{M}-\mathrm{NaCl}+$ 0.015 M-trisodium citrate, $\mathrm{pH} 7.0$ ) to a concentration of about $2.5 \mathrm{mg} . / \mathrm{ml}$. and stored at $-20^{\circ}$. The average yield was about $2 \mathrm{mg}$. and the DNA was found free of RNA and protein. Determination of sedimentation velocities by the band sedimentation method (Bruner \& Vinograd, 1965) yielded a molecular weight higher than $10^{7}$ daltons for the nuclear DNA extracted in this manner. The integrity of the DNA was judged from thermal denaturation curves and from films obtained by ultraviolet photography of DNA spun to equilibrium in a $\mathrm{CsCl}$ density gradient in the Spinco model-E analytical ultracentrifuge (Schildkraut, Marmur \& Doty, 1962). Whole cell DNA from some of the Candida species investigated here contain a minor satellite DNA (Stenderup \& Leth Bak, I968). This satellite DNA may constitute up to $5 \%$ of the total DNA and is shown to be of mitochondrial origin (A. Leth Bak, O. Christiansen \& A. Stenderup, to be published). Small amounts of this rapidly renaturating DNA (Borst, Kroon \& Ruttenberg, 1966) could seriously affect the results of the hybridization studies. Sedimentation of the cell homogenate through the $60 \%$ sucrose buffer, containing $\mathrm{Mg}$ ions and Triton $\mathrm{X}-\mathrm{I00}$, was in all instances able to remove all mitochondrial DNA from the DNA isolated from the sedimented nuclei.

Formation and detection of DNA-RNA hybrids. The procedure of Gillespie \& Spiegelman (1965) was used. Radioactive complementary RNA was synthesized in vitro with each DNA as template. The radioactive RNA was allowed to react with single-stranded DNA immobilized on membrane filters, and the degree of hybridization determined as the radioactivity retained on these filters.

Radioactive RNA production. DNA-dependent RNA polymerase isolated from Micrococcus lysodeikticus was obtained from Sigma Chemical Co. Adenosine triphosphate- ${ }^{3} \mathrm{H}$, cytosine triphosphate $-{ }^{3} \mathrm{H}$, guanosine triphosphate- ${ }^{3} \mathrm{H}$ and uridine tri- 
phosphate- ${ }^{3} \mathrm{H}$ were obtained from Schwartz Bio Research Inc. The corresponding unlabelled ribonucleoside triphosphates were obtained from Sigma Chemical Co. A carrier RNA for the small amounts of yeast RNA synthesized was obtained by extraction of RNA from Escherichia coli в by the method of Scherrer \& Darnell (I962). The conditions for synthesizing radioactive RNA were those described by Nakamoto, Fox \& Weiss (1964). The reaction mixture contained $30 \mu \mathrm{g}$. of primer DNA, 20 $\mathrm{m} \mu \mathrm{n} \equiv \mathrm{IO}^{-9}$ moles of each of the labelled and unlabelled ribonucleoside triphosphates, $\mathrm{I} 2.5 \mu$ moles of tris (hydroxymethyl) aminomethane- $\mathrm{HCl}(\mathrm{pH} \mathrm{7.5)}, 0.20 \mu$ moles spermidine phosphate, $0.30 \mu$ moles of $\mathrm{MnCl}_{2}$ and 20 units of RNA polymerase. The total volume was about $0.125 \mathrm{ml}$. The reaction mixture was incubated at $37^{\circ}$ for 30 min., after which $0.010 \mathrm{ml} .0 .1 \mathrm{M}-\mathrm{MgCl}_{2}, 0.150 \mathrm{ml}$. of carrier RNA solution (containing I.5 mg. Escherichia coli B RNA), and $0.050 \mathrm{ml}$. of a deoxyribonuclease solution containing $50 \mu \mathrm{g}$ DNase I (Worthington Biochemical Corp.) were added. Incubation was continued for an additional $20 \mathrm{~min}$. and the RNA isolated by the hot phenol, sodium dodecyl sulphate procedure of Scherrer \& Darnell (I962). The final precipitate of radioactive RNA with the carrier RNA was dissolved in 0.5 to $\mathrm{I} \cdot 0 \mathrm{ml}$. of $2 \times \mathrm{SSC}+$ $0.05 \%$ SDS (sodium dodecyl sulphate) and stored at $-20^{\circ}$. An assay was done for each RNA synthesized. RNA solution $(0.005 \mathrm{ml}$.) was mixed with $3 \mathrm{ml} .5 \%$ trichloracetic acid and filtered through a membrane filter (millipore, HAWP), washed with $20 \mathrm{ml} .5 \%$ trichloracetic acid and assayed for radioactivity as described below.

Gillespie and Spiegelman procedure for formation of DNA-RNA hybrids. $10 \mu \mathrm{g}$. of DNA in $0.5 \mathrm{ml} .0 .0 \mathrm{I} \times \mathrm{SSC}$ was heated at $100^{\circ}$ for $10 \mathrm{~min}$, quenched in ice and made to $5 \mathrm{ml}$. with cold $2 \times \mathrm{SSC}$. The denaturated DNA was filtered through a membrane filter (Millipore HAWP, $20 \mathrm{~mm}$.) and the filter washed with $100 \mathrm{ml}$. cold $2 \times$ SSC. The filter was dried at $25^{\circ}$ overnight, and then heated to $80^{\circ}$ for $2 \mathrm{hr}$. Hybridizations took place in glass scintillation vials. The filters were placed flat on the bottom of these vials and overlaid with the radioactive RNA in $0.5 \mathrm{ml} .2 \times \mathrm{SSC}$. Incubation was carried out for $16 \mathrm{hr}$ at $73^{\circ}$. The filters were then washed with $73^{\circ}$ warm $2 \times \mathrm{SSC}$ and treated with ribonuclease as described (Gillespie \& Spiegelman, 1965).

Lay-out of experiments, counting of radioactivity and statistical analysis of results. Equal amounts of radioactive RNA were added to three or four DNA filters for each DNA to be compared. Nonspecific binding of radioactivity was determined by adding the same amount of RNA to four blank filters in each experiment. The nonspecific binding was generally lower than $0.05 \%$ of input radioactivity. The filters were assayed for radioactivity in a liquid scintillation counter (Packard Tri-Carb scintillation spectrometer, model 3320). They were counted in plastic vials and a toluene scintillation solution containing $0.03 \%$ POPOP and $0.4 \%$ PPO (Packard). The efficiency of counting was $19 \%$ with a background of 22 c.p.m. The statistical counting error was less than $\pm \mathrm{I} \%$. All individual counts were corrected for nonspecific binding by subtraction of average blank. The statistical methods used are described in detail by Alling (1967) and exemplified in the paper of Weissman et al. (1966).

\section{RESULTS}

Relationships among Candida albicans, C. claussenii, C stellatoidea and C. tropicalis. Table $2 \mathrm{~A}$ gives the mean counts for reactions between DNA filters containing singlestranded DNA from C. albicans, C. claussenii, C. stellatoidea and C. tropicalis, 
respectively, and radioactive complementary RNA synthesized with DNA from each of these organisms as template. The mutual DNA-RNA reaction yields between $C$. albicans, $C$. claussenii and $C$. stellatoidea were high and of the same order of magnitude. By contrast, surprisingly low reaction yields were found between nucleic acids from these species and nucleic acids from $C$. tropicalis. This result was confirmed by experiments with two different DNA preparations from the same strains of $C$. albicans

Table 2. Relationships among Candida albicans, C. claussenii, C. stellatoidea and C. tropicalis

A. Mean counts of triplicate assays of radioactivity retained on filters after reaction between DNA and radioactive RNA synthesized with each DNA as template*

Source of template for radioactive RNA
C. a'bicans
C. claussenii
C. stellatoidea
C. tropicalis

Source of DNA tested

B. Relatedness values for $C$. albicans, $C$. claussenii and $C$. stellatoidea $\dagger$

\begin{tabular}{cccc}
\hline C. albicans & C. claussenii & C. stellatoidea & C. tropicalis \\
$\mathrm{I}, 726(100)$ & $1,188(69)$ & $\mathrm{I}, 39 \mathrm{I}(8 \mathrm{I})$ & $147(9)$ \\
$\mathrm{I}, 479(56)$ & $2,647(\mathrm{IO0})$ & $2,089(79)$ & $267(10)$ \\
$985(65)$ & $993(66)$ & $\mathrm{I}, 5 \mathrm{I} 5(100)$ & $188(\mathrm{I})$ \\
$135(6)$ & $82(4)$ & $134(6)$ & $2,264(100)$
\end{tabular}

C. claussenii

C. stellatoidea

$$
\begin{gathered}
\text { C. albicans } \\
0.38 \\
0.51
\end{gathered}
$$

C. claussenii

$$
0.5 \mathrm{I}
$$

* Different amounts of RNA were employed for each separate experiment (190,000 to 265,000 c.p.m.), making comparisons possible only within rows. Values in parentheses are per cent bindings in heterologous reactions relative to the bindings in homologous reactions taken as $100 \%$.

$\dagger$ See Methods for method of calculation. The $99 \%$ confidence interval for indistinguishable DNA preparations was 0.54 to $\mathrm{I} \cdot 87$.

and $C$. tropicalis. The experiment was also repeated with another strain of $C$. tropicalis (CBS I80/88). The DNA from this strain and the strain of $C$. tropicalis in Table I were found to be indistinguishable. Whether the small counts in the $C$. tropicalis heterologous reactions were significant was tested in experiments in which filters containing DNA isolated from Escherichia coli $\mathrm{B}$ were reacted with radioactive RNA synthesized with DNA from different yeast species as templates. The amounts of radioactivity retained in these experiments did not differ significantly from the non-specific bindings to blank filters. The relative homology (average per cent binding in heterologous reactions) between $C$. albicans, $C$. claussenii and $C$. stellatoidea is 63 to $73 \%$ (Table I), indicating that these species must be closely related. The three species are, however, distinguishable at the $99 \%$ confidence limit as seen from the relatedness statistics (Table $2 \mathrm{~B}$ ) (relatedness values from 0.38 to $0.5 \mathrm{I}$, lower $99 \%$ confidence limit $0.54) ; C$. tropicalis is only remotely related to any of the species $C$. albicans, $C$. claussenii and $C$. stellatoidea ( 7 to $9 \%$ relative binding (Tabler)).

Relationships among Candida albicans, C. melinii, C. pelliculosa and C. pseudotropicalis. Mean counts for the DNA-RNA reactions for nucleic acids from $C$. albicans, C. melinii, C. pelliculosa and C. pseudotropicalis and the relative homology between these species are seen in Table 3 and Table $I$, respectively. In the reactions between $C$. pelliculosa and $C$. pseudotropicalis an average of $32 \%$ relative binding was found in the heterologous reactions. The relative homology for the other combinations in this series was low ( 7 to $15 \%$ ). 
Relationships among Candida albicans, C. brumptii, C. catenulata and C. zeylanoides. Single-stranded DNA on filters and radioactive RNA synthesized with DNA from each of C. albicans, C. brumptii, C. catenulata and C. zeylanoides as template were reacted under conditions for DNA-RNA hybrid formation. The reaction yields for these reactions (Table $4 \mathrm{~A}$ ) and the calculated relative homology (Table I) show that C. brumptii and C. catenulata are closely related $(75 \%)$. These two species were distinguishable (relatedness value 0.56 lower $99 \%$ confidence limit 0.57 ) (Table ${ }_{4} \mathrm{~B}$ ). C. zeylanoides showed a somewhat higher relationship to $C$. brumptii and $C$. catenulata ( $7 \%$ and $22 \%$ ), than did any of the three species to C. albicans (10 to $13 \%$ ).

\section{Table 3. Relationships among Candida albicans, C. melinii, C. pelliculosa and C. pseudotropicalis}

Mean counts of triplicate assays of radioactivity retained on filters after reaction between DNA and radioactive RNA synthesized with each DNA as template*
Source of template for radioactive RNA
C. albicans
C. melinii
C. pelliculosa
C. pseudotropicalis

Source of DNA tested

\begin{tabular}{|c|c|c|c|}
\hline C. albicans & C. melinii & C. pelliculosa & $\begin{array}{l}\text { C. pseudo- } \\
\text { tropicalis }\end{array}$ \\
\hline $2,710(100)$ & 2 II (8) & 318 (I2) & 268 (I0) \\
\hline $254(5)$ & $4,918(100)$ & 577 (12) & 532 (II) \\
\hline $96(9)$ & 185 (I 8) & $1,042(100)$ & $358(34)$ \\
\hline $158(5)$ & $310(10)$ & $957(30)$ & $3,180(100)$ \\
\hline
\end{tabular}

* Different amounts of RNA were employed for each separate experiment (250,000 to 400,000 c.p.m.) making comparisons possible only within rows. Values in parentheses are per cent bindings in heterologous reactions relative to the bindings in homologous reactions taken as $100 \%$.

\section{Table 4. Relationships among Candida albicans, C. brumptii, C. catenulata and C. zeylanoides}

A. Mean counts of triplicate assays of radioactivity retained on filters after reaction between DNA and radioactive RNA synthesized with each DNA as template*

Source of template for radioactive RNA

\section{C. albicans}

C. brumptii

C. catenulata

C. zeylanoides
Source of DNA tested

\begin{tabular}{|c|c|c|c|}
\hline C. albicans & C. brumptii & C. catenulata & C. zeylanoides \\
\hline $973(100)$ & $4 I \quad(4)$ & $48(5)$ & $103(11)$ \\
\hline I72(I5) & I,III $(100)$ & $767(69)$ & $302(27)$ \\
\hline $280(20)$ & $\mathrm{I}, \mathrm{I} 44(8 \mathrm{I})$ & I,419 (100) & $498(35)$ \\
\hline 240 (10) & $158(7)$ & I35 (6) & $2,29 \mathrm{I}(100)$ \\
\hline
\end{tabular}

\section{C. catenulata}

$$
\text { - } \quad 0.56
$$

\section{C. brumptii}

* Different amounts of RNA were employed for each separate experiment (I75,000 to 225,000 c.p.m.), making comparisons possible only within rows. Values in parentheses are per cent bindings in heterologous reactions relative to the bindings in homologous reactions taken as $100 \%$.

$\uparrow$ The $99 \%$ confidence interval for indistinguishable DNA preparations was 0.57 to $I \cdot 76$.

Relationships among Candida albicans, C. pelliculosa and Hansenula anomala. Reaction yields (Table $5 \mathrm{~A}$ ) and relative homology (8I \%) (Table $\mathrm{I}$ ) show a close relationship between $C$. pelliculosa and $H$. anomala. The two species could not be distinguished by the accuracy obtained in this experiment (relatedness value $0 \cdot 66$, lower $99 \%$ 
confidence limit 0.53 ) (Table 5B). The relative homology between $C$. pelliculosa and C. albicans ( $14 \%$ ) is close to that found earlier ( $11 \%$ ), and close to that found for H. anomala and C. albicans (1 $2 \%$ ) (Table I).

\title{
Table 5. Relationships among Candida albicans, C. pelliculosa and Hansenula anomala
}

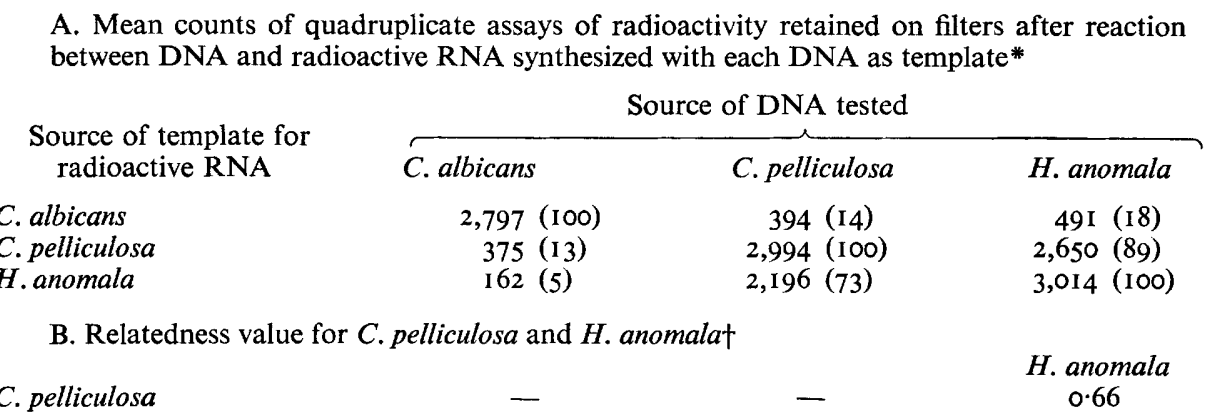

* Different amounts of RNA were employed for each separate experiment (I90,000 to 265,000 c.p.m.), making comparisons possible only within rows. Values in parentheses are per cent bindings in heterologous reactions relative to the bindings in homologous reactions taken as $100 \%$.

$\uparrow$ The $99 \%$ confidence interval for indistinguishable DNA preparations was 0.53 to I $\cdot 88$.

\section{Table 6. Relationships among Candida albicans, C. pseudotropicalis and Kluyveromyces fragilis}

\begin{abstract}
A. Mean counts of quadruplicate assays of radioactivity retained on filters after reaction
\end{abstract} between DNA and radioactive RNA synthesized with each DNA as template*

Source of template for radioactive RNA

C. albicans

C. pseudotropicalis

Kl. fragilis
Source of DNA tested

$\begin{array}{ccc}\text { C. albicans } & \text { C.pseudotropicalis } & \text { Kl. fragilis } \\ 2,424(\text { I00) } & 322(13) & 320(13) \\ 190(7) & 2,537(100) & 2,554(101) \\ 368 \text { (5) } & 5,794(82) & 7,101 \text { (100) }\end{array}$

B. Relatedness value for $C$. pseudotropicalis and $K l$. fragilis $\dagger$

$\begin{array}{lllc}\text { C.pseudotropicalis } & - & - & K l \text { fragilis } \\ 0.8 \mathrm{I}\end{array}$

* Different amounts of RNA were employed for each separate experiment (285,000 to 304,000 c.p.m.), making comparisons possible only within rows. Values in parentheses are per cent bindings in heterologous reactions relative to the bindings in homologous reactions taken as $100 \%$.

+ The $99 \%$ confidence interval for indistinguishable DNA preparations was $0 \cdot 70$ to $1 \cdot 43$.

Relationships among Candida albicans, C. pseudotropicalis and Kluyveromyces fragilis. The results in Table $6 \mathrm{~A}$ and Table $\mathrm{I}$ indicate a close relationship between $C$. pseudotropicalis and $\mathrm{Kl}$. fragilis, relative homology ( $92 \%$ ). The relatedness value for these two species is $0.8 \mathrm{I}$ and the lower $99 \%$ confidence limit for indistinguishable DNAs $0 \cdot 70$, showing that the two species are not distinguishable. The relative bindings in the reactions between $K l$. fragilis and $C$. albicans, average ( $9 \%$ ), are close to those for $C$. pseudotropicalis and C. albicans (10\%), and are a reproduction of the value for these two species listed in Table I $(8 \%)$.

Relationships among Candida albicans, C. melinii and Hansenula wingei. Also C. 
melinii and $H$. wingei (relative homology $97 \%$ ) are seen to be very closely related (Table $7 \mathrm{~A}$ and Table $\mathrm{I}$ ). The relatedness value between these two species is 0.92 , lower $99 \%$ confidence limit 0.62 , showing that the species are not to be distinguished, in this experiment (Table $7 \mathrm{~B}$ ). The relative homology between $C$. albicans and $C$. melinii $(5 \%)$ and between $C$. albicans and $H$. wingei $(4 \%)$ is very close to the value for $C$. albicans and C. melinii ( $7 \%$ ) found in another experiment (Table $\mathrm{I}$ ).

\section{Table 7. Relationships among Candida albicans, C. melinii and Hansenula wingei}

A. Mean counts of quadruplicate assays of radioactivity retained on filters after reaction between DNA and radioactive RNA synthesized with each DNA as template*

Source of template for radioactive RNA

C. albicans

C. melinii

$H$. wingei
Source of DNA tested

\begin{tabular}{ccc}
\hline C. albicans & C. melinii & $H$. wingei \\
$3,063(\mathrm{I00})$ & $9(0)$ & $76(2)$ \\
$687(9)$ & $7,985(100)$ & $7,504(94)$ \\
$57(6)$ & $931(100)$ & $929(100)$
\end{tabular}

$H$. wingei

0.92

H.winge
$-\quad 0.92$

C. melinii

$\uparrow$ Different amounts of RNA were employed for each separate experiment (200,000 to 300,000 c.p.m.), making comparisons possible only within rows. Values in parentheses are per cent bindings in heterologous reactions relative to the bindings in homologous reactions taken as $100 \%$.

* The $99 \%$ confidence interval for indistinguishable DNA preparations was 0.62 to $\mathrm{I} \cdot 6 \mathrm{I}$.

\section{DISCUSSION}

The genus Candida has previously been considered to be a heterogenous group composed of members with different morphological, biochemical and ecological characteristics. This heterogeneity is reflected in a great variation in DNA base composition among several of the different members of the group. (Stenderup \& Leth Bak, 1968). The nucleic acid homology technique confirms this suggested heterogeneity in genetic relatedness for several of the Candida species investigated in this study, close relationships being observed only between $C$. albicans, $C$. claussenii, and $C$. stellatoidea and between $C$. brumptii and $C$. catenulata.

The great genetic relatedness between Candida albicans, $C$. claussenii and $C$. stellatoidea is in agreement with the conventional classification. Although distinguishable, similarity in morphology, antigenic composition and biochemical reactions is seen in these species. The GC content of their DNA is also very similar (Table r).

Although morphologically different from Candida albicans, $C$. claussenii and $C$. stellatoidea, the serology, biochemical reactions and DNA base composition of $C$. tropicalis might have suggested a closer relationship to these species. The close relationship between $C$. brumptii and $C$. catenulata might have been expected on the basis of their characteristic thermal denaturation curves (Stenderup \& Leth Bak, 1968).

The genetic similarity was in all other cases surprisingly low. This low genetic relatedness might in some cases be explained by the fact that a number of Candida species are considered imperfect counterparts of species within various perfect genera. Thus $C$. pelliculosa, $C$. pseudotropicalis and $C$. melinii are considered the imperfect 
stages of Hansenula anomala, Kluyveromyces fragilis and $H$. wingei respectively (Wickerham \& Burton, 1954; Diddens \& Lodder, 1938; L. J. Wickerham, personal communication). The results of the DNA-RNA hybrid experiments indicating that the DNA from these pairs are indistinguishable, give strong support for the transfer of these Candida species to the respective perfect genera.

It appears from Table I that all the very closely related species also have nearly identical GC content of their DNA, the only exceptions are Candida pelliculosa-C. pseudotropicalis, which show some $30 \%$ relative bindings despite of a difference in GC content of about $4.0 \%$.

The low reactions ( 5 to $10 \%$ ) between species which actually may belong to different genera might indicate some degree of genetic relatedness among all yeasts. If this be so, it might indicate a common phylogeny of these organisms. Part of these common base sequences might be explained by the findings that ribosomal RNA cistrons seem to have been highly conserved among fungi (Bicknell \& Douglas, 1969) and that the genes coding for the ribosomal RNA occupy about $2 \cdot 5 \%$ of the whole genome in yeast (Schweizer, MacKecknie \& Halvorson, 1969).

The relative homology ideally constitute a quantitative measure of the fractional similarity between genomes. However, there are several reservations to be made. The degree of homology measured is not independent of the incubation temperature (Johnson \& Ordal, I968; Kingsbury, Fanning, Johnson \& Brenner, 1969). A hybridization temperature of $73^{\circ}$ (which is $\mathrm{Tm}-25^{\circ}$ in $2 \times \mathrm{SSC}$ for Candida zeylanoides) have been chosen for all hybridizations in this study. This temperature may be unnecessarily high for the reactions with the DNAs of the lower GC content. However we believe that higher hybridization temperatures (although the bindings may be somewhat lower) will only heighten the accuracy and discrimination in these experiments.

The possibility may also exist that the kind of RNA polymerase (from Micrococcus lysodeikticus) used in these experiments would not synthesize RNA complementary to both DNA strands in equal amounts or would not copy all regions on the yeast primer DNA with equal frequency. Such asymetric and selective transcription has already been shown for the in vitro transcription of intact native $\lambda$ phage DNA (Cohen \& Hurwitz, 1967) and T4 phage DNA (Geiduschek, Snyder, Colvill \& Sarnat, 1966) by Escherichia coli RNA polymerase. No such selective copying has been reported for the in vitro transcription of bacterial DNA. Dubnau, Smith, Morell \& Marmur (1965) have in DNA-RNA hybridization studies found the same degree of homology between Bacillus subtilis and several other members of the genus Bacillus, using either 'pulse labelled' RNA or RNA synthesized in vitro.

Generally, the results reported here prove the applicability and significance of the nucleic acid homology technique as a tool in a rational taxonomy of yeasts. The results were found reproducible, and the accuracy of the determinations is comparable to that of others using similar methods for the detection of nucleic acid homology among bacteria and mycoplasmas. (Somerson et al. 1966; Weissman et al. 1966).

The authors thank Mr. A. J. Therkelsen for helpful advice on the statistical analysis. This investigation was supported by grant from the Danish State Research Foundation and the P. Carl Petersen Foundation. 


\section{REFERENCES}

Alling, D. W. (1967). Tests of relatedness. Biometrika 54, 459.

Bicknell, J. N. \& Douglas, H. C. (1969). Conservation of ribosomal RNA sequences in yeast, filamentous fungi and plants. Bact. Proc. p. 39.

Borst, P., Kroon, A. M. \& Ruttenberg, G. J. C. M. (I966). Symposium on Structure and Function of Genetic Elements. Warsaw. 1967, p. 85, London and Warsaw: Academic Press and P.W.N.

BRUNer, R. \& Vinograd, J. (1965). The evaluation of standard sedimentation coefficients of sodium RNA and sodium DNA from sedimentation velocity data in concentrated $\mathrm{NaCl}$ and $\mathrm{CsCl}$ solutions. Biochim. biophys. Acta 108, 18.

Cohen, S. N. \& Hurwitz, J. (I967). Transcription of complementary strands of phage $\lambda$ DNA in vivo and in vitro. Proc. natn. Acad. Sci. U.S.A. 57, 1759.

De Ley, J., Park, J. W., Tijtgat, R. \& van ERmengem, J. (1966). DNA homology and taxonomy of Pseudomonas and Xanthomonas. J. gen. Microbiol. 42, 43.

DidDens, H. A. \& LodDer, J. (I938). On some sporogenous yeasts and their imperfect stages. Mycol. appl. 2, 28.

Dubnau, D., Smith, I., Morell, P. \& Marmur, J. (I965). Gene conservation in Bacillus species. I. Conserved genetic and nucleic acid base sequence homologies. Proc. natn. Acad. Sci. U.S.A. $54,49 I$.

Geiduschek, E. P., Snyder, L., Colvill, A. J. E. \& Sarnat, M. (1966). Selective synthesis of T-even bacteriophage early messenger in vitro. J. molec. Biol. 19, 54I.

Gillespie, D. \& SpIegelman, S. (I965). A quantitative assay for DNA-RNA hybrids with DNA immobilized on a membrane. J. molec. Biol. 12, 829 .

Johnson, J. L. \& Ordal, E. J. (1968). Deoxyribonucleic acid homology in bacterial taxonomy: Effect of incubation temperature on reaction specificity. J. Bact. 95, 893 .

Kingsbury, D. T., FAnning, G. R., Johnson, K. E. \& Brenner, D. J. (1969). Thermal stability of interspecies Neisseria DNA duplexes. J. gen. Microbiol. 55, $20 \mathrm{I}$.

Lodder, J. \& Kreger-VAN Ru, J. J. W. (1952). The Yeasts. A Taxonomic Study. Amsterdam: North Holland Publishing Co.; New York: Interscience Publishers Inc.

MARMur, J. (I96I). A procedure for the isolation of deoxyribonucleic acid from micro-organisms. J. molec. Biol. 3, 208.

Nakamoto, T., Fox, C. F. \& Weiss, S. B. (1964). Enzymatic synthesis of ribonucleic acid. I. Preparation of ribonucleic acid polymerase from extracts of Micrococcus lysodeikticus. J. biol. Chem. 239, 167.

SCHerrer, K. \& DARnell, J. E. (I962). Sedimentation characteristics of rapidly labelled RNA from HeLa cells. Biochem. biophys. Res. Commun. 7, 486.

Schildkraut, C. L., Marmur, J. \& Doty, P. (I962). Determination of the base composition of deoxyribonucleic acid from its buoyant density in CsCl. J. molec. Biol. 4, 430.

Schweizer, E., MacKechnie, C. \& Halvorson, H. O. (1969). The redundancy of ribosomal and transfer RNA genes in Saccharomyces cerevisiae. J. molec. Biol. 40, 26I.

Somerson, N. L., Reich, P. R., Walls, B. E., Chanock, R. M. \& Weissman, S. M. (I966). Genetic differentiation by nucleic acid homology. II. Genotypic variations within two Mycoplasma species. J. Bact. 92, 3 I I.

Stenderup, A. \& LeTh BAK, A. (1968). Deoxyribonucleic acid base composition of some species within the genus Candida.J. gen. Microbiol. 52, $23 \mathrm{I}$.

Weissman, S. M., Reich, P. R., Somerson, N. L. \& Cole, R. M. (i966). Genetic differentiation by nucleic acid homology. IV. Relationships among Lancefield groups and serotypes of Streptococci. J. Bact. 92, 1372.

Wickerham, L. J. \& Burton, K. A. (1954). A simple technique for obtaining mating types in heterothallic diploid yeasts, with special reference to their uses in the genus Hansenula. J. Bact. 67, 303 . 